\author{
Roman KWIECIEŃ \\ Uniwersytet Ekonomiczny w Krakowie \\ roman.piotr.kwiecien@gmail.com
}

\title{
OBSERWATORA I UCZESTNIKA SPOJRZENIA NA WOJNE ALBO O OBOJĘTNOŚCI I ZAANGAŻOWANIU
}

\author{
ROZWAŻANIA W ŚWIETLE FILOZOFII KANTA
}

ABSTRACT Observer's and participant's views on war or about indifference and commitment. Deliberations under Kant's philosophy

The article seeks to draw attention to Kant's look at war and its importance for today's debate on the use of force. Kant's views on war are usually considered equivalent with his standpoint presented in Zum ewigen Frieden. However, Kant's political philosophy offers broader perspective of the war problem. This perspective takes into account two standpoints, namely, the non-involved observer standpoint and the committed participant one. The former tries to explain the war phenomenon, whereas the latter assesses it. Surprisingly enough, war can make to Kant a measure of progress within human society and leads to a real civitas gentium, that is, to society without wars which embodied the ideal of 'perpetual peace'. According to Kant, such progress must be grounded on 'revolution of freedom' because individual human freedom conditions both moral maturity of mankind and political freedom. Unfortunately, taking into account a practise of domestic and international relations Kant turned out to be an excessive optimist.

Key words: Kant's political philosophy, war, peace, perpetual peace, freedom

Słowa kluczowe: filozofia polityczna Kanta, wojna, pokój, wieczny pokój, wolność 
$\mathrm{P}$ ostrzeganie wojny pozostaje zawieszone między jej pacyfistycznym bezwarunkowym potępieniem a realistyczną akceptacją uznającą ją - jak ujął to Carl von Clausewitz - za kontynuowanie polityki innymi środkami ${ }^{1}$. Spór o wojnę rozpostarty między tymi biegunami dotyczy tego, czy, kiedy i po spełnieniu jakich warunków uzasadnione jest użycie siły zbrojnej. Taką legitymizowaną wojnę język prawa od starożytności określa jako bellum legale, zaś język etyki nazywa bellum iustum. Pojawia się tu naturalnie pytanie, czy bellum legale to bellum iustum. Nie jest to problem obcy współczesnej nauce prawa międzynarodowego i filozofii prawa. Zajmował on również Kanta, który najpełniejszy wyraz dał mu w swej najsłynniejszej rozprawie z filozofii politycznej - Zum ewigen Frieden. Nie to zagadnienie jednak interesować nas będzie przede wszystkim w przedkładanym artykule. Nacisk położymy w nim na pewną dwutorowość charakteryzującą Kanta myślenie o wojnie; dwutorowość, która często jest pomijana w recepcji filozofii politycznej autora Krytyki czystego rozumu. Ze względu na dążenie do unikania powierzchowności sądów o działaniach zbrojnych i tym samym ich banalizacji powinna ona, w przekonaniu autora, stanowić ważny punkt odniesienia w trwających dyskusjach o wojnie.

Kant nie pozostawił po sobie kompletnego wykładu filozofii politycznej, co w pewnej mierze przyczyniło się do spotęgowania rozdźwięku jakoby obecnego w jego poglądach o wojnie. Zasadnie Hannah Arendt zwraca uwagę na potrzebę szukania filozofii politycznej Kanta w całej jego twórczości, nie zaś jedynie w tych kilku esejach, które zwykle można znaleźć w zbiorach zatytułowanych „pisma polityczne”2. Rzeczywiście, na dorobek Kanta w zakresie filozofii politycznej składają się prace powstałe w różnych okresach jego twórczości, również w okresie przedkrytycznym. Tym niekiedy tłumaczono domniemywane rozbieżności jego sądów o wojnie. Nie wydaje się to jednak wystarczającym wyjaśnieniem. Te domniemane rozbieżności czy niespójności wynikają przede wszystkim z rozpatrywania przez autora Krytyk problemu wojny z dwóch perspektyw: obserwatora oraz bezpośrednio zaangażowanego, czyli uczestnika, albo filozofa kierującego się rozumem teoretycznym oraz podmiotu etycznego ${ }^{3}$. Odpowiadają oni na inne pytania w swym postrzeganiu wojny. Ten pierwszy - obserwator (filozof) pyta: co mogę wiedzieć?, drugi zaś: jak powinienem żyć? Dopiero uwzględnienie tych dwóch perspektyw pozwala na uchwycenie stanowiska Kanta w przedmiocie wojny i jego znaczenia dla toczonego dzisiaj na jej temat dyskursu, zwłaszcza o możliwości pogodzenia stanowisk obserwatora i uczestnika.

Lektura pism Kanta zachęca do krytycznej analizy jego myśli. Wolność myślenia to główne znamię filozofii, zaś rozum gra w niej rolę najwyższego trybunału. Przed jego osądem nie może być chroniony żaden autor. Interpretując w Krytyce czystego rozumu

C. von Clausewitz, O wojnie, t. 1, przeł. A. Cichowicz, L. Koc, Warszawa 1958, s. 32.

2 H. Arendt, Wyktady o filozofii politycznej Kanta, przeł. R. Kuczyński, M. Moskalewicz, Warszawa 2012, s. 55.

3 Znaczenie tych perspektyw w Kantowskiej filozofii politycznej podkreśla Hannah Arendt. Zob. tam$\dot{z} e$, s. 98-99. 
znaczenie idei w filozofii Platona, Kant zauważył: Nie jest niczym niezwyktym, zarówno w prostej rozmowie, jak i w pismach, dzięki porównywaniu myśli, które pewien autor wypowiada o swym przedmiocie, rozumieć go nawet lepiej, niż on sam siebie rozumiat, nie określiwszy dostatecznie swego pojęcia i wskutek tego czasami mówią, a także myśląc cośwbrew wtasnej intencji $i^{4}$ Czy rzeczywiście potomność, kierując się tą dyrektywą, jest w stanie lepiej wyjaśniać od samego Kanta rozdźwięk między stanowiskami obserwatora i uczestnika wobec wojny? Czy można Kantowi w tym zakresie zarzucić niekonsekwencję? Jeśli nie, czy to, co autor Metafizyki moralności powiedział o wojnie, wciąż pozostaje ważne i aktualne? Udzielenie odpowiedzi na te pytania moderować będzie tok analiz składających się na przedkładany artykuł.

Królewiecki filozof w niejednym miejscu zwraca uwagę na przewrotność racjonalnego dyskursu, to znaczy na możliwość sprowadzenia na manowce przez zdolność rozumowania. Nazywa to „skandalem rozumu”. Toteż rozum wymaga krytyki, która pozwala na odkrycie jego źródeł i ograniczeń. Krytyka to warunek oczyszczenia rozumu, co z jednej strony pozwala na przeciwstawienie się dogmatycznej metafizyce, z drugiej strony zaś na odrzucenie sceptycyzmu. Zetknięcie z tym drugim pozwala jednak, czego sam Kant doświadczył i czemu dawał bezpośredni wyraz, odnosząc się w swych pismach do myśli Hume’a, na wybudzenie się z „metafizycznej drzemki”. Krytyka rozumu ma również konsekwencje praktyczne. Dotyczą one nie tylko etycznego wymiaru jednostkowego życia, czym filozof z Królewca zajmował się w drugiej Krytyce, lecz również wolności politycznej człowieka rozumianej jako wolność każdego członka społeczności i definiowanej przezeń jako wolność, by czynić ze swego rozumu publiczny użytek5, czyli wolność realizowaną w wymiarze społecznym, zarówno wewnątrzpaństwowym, jak i międzynarodowym.

Napotykamy w tym miejscu w filozofii Kanta pomost łączący rozum w jego użyciu teoretycznym z rozumem praktycznym. Otóż prawda, czyli najwyższa wartość rozumu czystego, nie może uzyskać powszechnej ważności bez tego, co pozostaje najważniejsze dla rozumu w jego praktycznym użyciu - wolności. I nie chodzi tutaj przede wszystkim o wolność transcendentalną (egzystencjalną), kluczową dla akceptacji i kierowania się przez podmiot etyczny imperatywem kategorycznym, lecz właśnie o wolność polityczną, czyli nieskrępowaną możliwość komunikowania innym wytworów własnej działalności, w tym twórczości. Myślenie teoretyczne, choć uprawiane w samotności, zależy od tych, do których trafiają jego owoce, czyli w pierwszym rzędzie od istnienia audytorium i możliwości zapoznania się przez jego członków z wynikami czyjejś myśli. Dlatego pozbawienie wolności publicznego dzielenia się myślą odbiera człowiekowi

I. Kant, Krytyka czystego rozumu, przeł. R. Ingarden, Kęty 2001, B 370, A 314, s. 303.

Tenże, Odpowiedź na pytanie: czym jest Oświecenie?, przeł. M. Żelazny, [w:] tenże, Rozprawy z filozofii historii, Kęty 2005, s. 45. Zob. również tenże, O porzekadle: to może być stuszne w teorii, ale nic nie jest warte w praktyce, [w:] tenże, O porzekadle: to może być stuszne $w$ teorii, ale nic nie jest warte $w$ praktyce. Do wiecznego pokoju. Projekt filozoficzny, przeł. M. Żelazny, Toruń 1995, s. 19-20; H. Arendt, What Is Freedom?, [w:] taż, Between Past and Future. Six Exercises in Political Thought, New York 1961, s. 145; taż, Wyktady..., s. 69; E. Nowak-Juchacz, Autonomia jako zasada etyczności. Kant, Fichte, Hegel, Wrocław 2002, s. 127-129; M. Żelazny, Idea wolności w filozofii Kanta, Toruń 1993, s. 191-194. 
w dłuższej perspektywie wolność myślenia. Traci się bowiem rację uzasadniającą myślenie, co w konsekwencji czyni bezprzedmiotową tę ludzką aktywność. Tak oto praktyka stosunków społecznych i to, co dla niej najważniejsze - wolność polityczna - uzasadniają i w dużym stopniu warunkują aktywność tych, którzy chcą wyjaśniać prawidła życia praktycznego, czyli tych, którzy parają się teoretycznym używaniem rozumu.

Powyższa wzmianka o stosunku teorii i praktyki w myśli Kanta niech służy jako swoiste prolegomena do jego filozofii wojny. Wspomnieliśmy już o obecnych w niej dwóch perspektywach patrzenia na wojnę: obserwatora (widza) oraz uczestnika, czyli tego, kto wyjaśnia, oraz tego, kto działa praktycznie. Dotykamy więc tutaj problemu, który Kant zwerbalizował w tytule jednego ze swych najgłośniejszych esejów z filozofii praktycznej, mianowicie: czy to, co słuszne w teorii, ma jakąkolwiek wartość w praktyce. Sam filozof z Królewca przekonany był o ścisłych związkach i uzupełnianiu się teorii i praktyki. Kończy wszak ten esej optymistyczną konkluzją: to, co na podstawie rozumu ma wartość w teorii, ma również wartość i w praktyce 6 .

Tok rozumowania Kanta w sprawie używania siły zbrojnej nie był jednowymiarowy. Nie można mu z pewnością przypisać roli dogmatycznego, bezrefleksyjnego pacyfisty ${ }^{7}$, choć taką etykietkę zdają się przypinać mu ci, którzy jego filozofię polityczną utożsamiają wyłącznie z Zum ewigen Frieden ${ }^{8}$. Kanta ogląd i ocena praktyki stosunków międzynarodowych wyzbyte były niewątpliwie złudzeń. Natura ludzka - pisał - nigdzie nie wydaje się tak niegodna mitości jak we wzajemnych stosunkach między narodami. Odnośnie do swej niezależności, czy swego stanu posiadania, żadne państwo nie może ani na moment być zabezpieczone przed innymi`. W swej najsłynniejszej rozprawie z filozofii politycznej wyraża nie mniej pesymistyczną opinię: Stan pokoju pośród ludzi żyjących obok siebie nie jest stanem naturalnym (status naturalis), którym raczej jest stan wojny, to jest jeśli nie ciagtej erupcji dziatań nieprzyjacielskich, to jednak ustawicznego nimi zagro$\dot{z} e n i a^{10}$. Konieczne do zapewnienia bezpieczeństwa zbrojenia często czynią pokój, czego Kant był w pełni świadom, bardziej ciężkim i dla wewnętrznego dobrobytu jeszcze

I. Kant, Oporzekadle..., s. 45.

7 Przytoczmy w tym miejscu ocenę Mirosława Żelaznego: Kant nie jest [...] marzycielem ani pacyfista $i$ zdaje sobie sprawę, że przynajmniej na obecnym etapie rozwoju ludzkości hasto Machiavellego „Wpolityce bezbronni prorocy nie zwyciężaja" wyraża po prostu stan faktyczny. [...] W polityce zagranicznej każdy naród ma prawo, a nawet obowiazek bronić swej wolności i swego poziomu rozwoju spotecznego nawet droga prowadzenia wojny - M. Żelazny, Idea wolności..., s. 216.

8 Nawet Hannah Arendt, która dostrzegała i doceniała wielowymiarowość myśli politycznej autora Krytyk, zauważyła w związku z tym, że o ile polityczne sympatie Kanta w kwestii rewolucji leżały wyraźnie po jej stronie, o tyle jego sympatie polityczne w sprawie wojny umiejscowiły się wyraźnie i całkowicie po stronie pokoju. H. Arendt, Wyktady..., s. 94. Odnośnie do poglądów Kanta na temat rewolucji, pamiętajmy jednak, że nie wyraża on swojego zdania na ten temat jednoznacznie. Dlatego Arendt mówi w tym względzie „jedynie” o „politycznych sympatiach” Kanta. Niemniej jednak trzeba wziąć pod uwagę jego sąd zawarty w napisanym po rewolucji francuskiej Zum ewigen Frieden: Prawo cztowieka musi zostać uznane za święte, chociażby panująca wtadzę miato to kosztować bardzo wiele poświęcenia I. Kant, Do wiecznego pokoju. Projekt filozoficzny, [w:] tenże, O porzekadle..., s. 89.

9 Tenże, Oporzekadle..., s. 44.

10 Tenże, Do wiecznego pokoju..., s. 55-56. 
bardziej destrukcyjnym aniżeli same działania wojenne ${ }^{11}$. W ten oto sposób filozof z Królewca odrzuca równowagę mocarstw jako środek zapewniania pokoju i tym samym podważa zasadność wywodzącej się jeszcze ze starożytności i przypisywanej Wegecjuszowi maksymy - „pragniesz pokoju, szykuj się do wojny”. Jedyny pokój, o jaki warto zabiegać, to „pokój wieczny”, to znaczy pokój trwały. Pokój tymczasowy to dla Kanta w gruncie rzeczy przeciwieństwo pokoju.

Autor Krytyk obrazowo potępia wojnę. Porównuje prowadzące ją narody do $z a-$ pijaczonych drabów oktadających się kijami w sklepie z porcelana ${ }^{12}$. Osąd bezpośrednio zaangażowanego podmiotu moralnego kierującego się prawidłami rozumu praktycznego jest tu bezkompromisowy - wojny nie powinny mieć miejsca. Rozpatrywany w Metafizyce moralności wątek dotyczący realizowanej przez Europejczyków środkami siłowymi misji cywilizacyjnej w różnych częściach świata kończy retorycznym dlań pytaniem: czy sprawiedliwość naprawdę wzrastać może na bezprawiu ${ }^{13}$ Zwróćmy uwagę na pojawiający się tu element nie tylko etycznego, ale i prawnego potępienia wojny. To uzupełniające się wymiary Kantowskiej filozofii wojny, która - na marginesie - daje jednoznaczną odpowiedź na postawione na początku niniejszego artykułu pytanie, czy bellum iustum to bellum legale. Prawne i etyczne aspekty wojen znalazły najpełniejsze i zarazem najstynniejsze rozwinięcie w Zum ewigen Frieden ${ }^{14}$. Świadczy o tym choćby następujący fragment: Pojęcie prawa narodów jako prawa do wojny wtaściwie w ogóle nie daje się pomyśleć [...], ponieważ należatoby przez nie rozumieć, że jest w petni sprawiedliwe, gdy nastawieni w taki sposób ludzie niszczą się nawzajem, a zatem że wieczny pokój znajda w gtębokiej mogile, kryjącej w sobie cata okropność gwattu, wraz z jego sprawcami ${ }^{15}$.

Etyczny i prawny wymiar wojny są u królewieckiego filozofa zbieżne, a z pewnością się nie wykluczają, ponieważ etyka i prawo to sfery, w których uzewnętrzniają się skutki prawodawstwa jednego rozumu praktycznego. Nakazy tego rozumu są zasadami autonomicznymi, gdyż nie warunkują ich żadne nakazy religijne, prawidła życia społecznego czy prawa naturalnego (przyrodniczego) porządku rzeczy. Dlatego Kant mówi tu o „czystym prawodawstwie” rozumu. Wynikające zeń prawa wolności zwie prawami moralnymi, w odróżnieniu od praw przyrody. Wśród praw wolności te, które odnoszą się do działań w sferze zewnętrznej, tworzą osobną kategorię praw o zastosowaniu jurydycznym, zaś prawa zawierające uzasadnienie właściwej i w tym znaczeniu pierwotnej podstawy działania to prawa etyczne ${ }^{16}$. Dlatego każde ludzkie działanie może być ocenianie i z moralnego, i z legalnego punktu widzenia. Sfera legalności to domena wolności zewnętrznej, zaś działania praw etycznych - wolności wewnętrznej, egzystencjalnej.

$11 \quad$ Tenże, O porzekadle..., s. 44.

12 Tenże, Wznowione pytanie. Czy ludzki rodzaj stale zmierza ku temu co lepsze?, przeł. M. Żelazny, [w:] tenże, Rozprawy..., s. 221.

13 Tenże, Metafizyka moralności, przeł. E. Nowak, Warszawa 2005, 353, §62, s. 207.

14 Szerzej: R. Kwiecień, Prawo w perspektywie filozofii Kanta, [w:] tenże, Między wartościa wspólnoty a wspólnota wartości. Studia i szkice z filozofii prawa idealizmu niemieckiego, Lublin 2007, s. 41-50.

15 I. Kant, Do wiecznego pokoju..., s. 64.

16 Tenże, Metafizyka..., 214, s. 18. 
Jest to jednak, pamiętajmy, ta sama wolność. Toteż choć czyn moralnie naganny może okazać się czynem, którego skutki są prawnie neutralne, w filozofii Kanta nie dochodzi do konfliktu między Moralität a Legalität ${ }^{17}$.

Przedstawione prawne i etyczne potępienie wojny to punkt widzenia podmiotu działającego i praktycznie zaangażowanego - uczestnika. Nie tworzy on jednak pełnego obrazu wojny w filozofii Kanta. Dopełnia go postrzeganie wojny przez obserwatora, który nie ocenia, lecz wyjaśnia. Ta perspektywa pojawia się przede wszystkim w jego Krytyce wtadzy sadzenia i w pismach z filozofii historii. Jest to perspektywa niezaangażowanego praktycznie podmiotu - filozofa. Brak zaangażowania pozwala mu dostrzec te aspekty wojen, które uczestnicy ignorują bądź jednoznacznie potępiają.

Jako że obserwator kieruje się władzą sądzenia, jego opinie o wojnach ujawnia przede wszystkim wspomniana trzecia Krytyka. Dzieli się ona, przypomnijmy, na krytykę estetycznej władzy sądzenia i krytykę teleologicznej władzy sądzenia. Ta pierwsza traktuje w znacznej części o sądzie smaku, który opiera się na racjach a priori i dotyczy kategorii piękna i wzniosłości. Krytyka teleologicznej władzy sądzenia mówi zaś o celowości przyrody, a szerzej - o miejscu człowieka w historii i jego wpływie na nią.

W obu częściach Krytyki wtadzy sądzenia znajdujemy ważne opinie o wojnie. Zacznijmy ich analizę od $\$ 28$. Czytamy w nim m.in.: Nawet wojna, jeśli prowadzona jest z zachowaniem porzadku i z poszanowaniem praw obywatelskich, ma w sobie coś wzniostego, przy czym czyni ona charakter narodu, który wiedzie ją w ten sposób, tym wznioślejszym, im liczniejsze byty niebezpieczeństwa, na jakie byt narażony i wśród których zdotat mężnie przetrwać. Natomiast dtugotrwaty pokój wiedzie zazwyczaj do panowania samego tylko ducha handlu, a wraz z nim do panowania niskiej chciwości, tchórzostwa i zniewieściatości oraz do upodlenia się sposobu myślenia narodü ${ }^{18}$. To zaskakująca - mogłoby się wydawać - opinia w świetle całokształtu filozofii politycznej Kanta; opinia, którą bez znajomości personaliów wypowiadającego ją autora można by przypisać Heglowi. Wszak to autor Fenomenologii ducha kojarzony jest głównie z apoteozą wojny w panoramie filozofów idealizmu niemieckiego. Hegel przecież upatrywał w wojnie czynnika wzmacniającego "zdrowie etyczne” narodów ${ }^{19}$. W czasie pokoju - głosił - życie obywatelskie bardziej się rozszerza, wszystkie sfery stają się osiedziate, a na dtuższq mete jest to wsiakanie ludzi w bagno; ich cechy partykularne staja sie coraz bardziej skrzepte $i$ kostniejaq. Wojna prowadzi tymczasem, wedle Hegla, do stabilizacji sytuacji wewnętrznej w państwach: wzmacnia władzę najwyższą i hamuje wybuch wewnętrznych niepokojów. Słowem, wyrywając ludzi ze stagnacji, mobilizuje wewnętrzne siły społeczne. Toteż zdaniem Hegla ludy wychodza z wojen nie tylko wzmocnione, lecz nawet narody, w których panuje niezgoda, osiagaja dzięki wojnie na zewnątrz spokój wewnątrz ${ }^{21}$.

17 Por. O. Höffe, Immanuel Kant, przeł. A. Kaniowski, wyd. 2 zm., Warszawa 2003, s. 168; R. Kwiecień, Prawo..., s. 34-35.

18 I. Kant, Krytyka wtadzy sądzenia, przeł. J. Gałecki, Warszawa 1986, 107, §28, s. 161.

19 Zob. G.W.F. Hegel, Zasady filozofii prawa, przeł. A. Landman, Warszawa 1969, §324, s. 317.

20 Tamże, \$324, uzupełnienie, s. 434.

21 Tamże. 
Spojrzenie na wojnę autora Nauki logiki to spojrzenie filozofa-obserwatora. Rozum teoretyczny jest dlań - parafrazując określenie Fichtego - „korzeniem wszelkiego rozumu".

W Krytyce wtadzy sądzenia taką postawę zdaje się też przyjmować Kant, czego wyrazem jest przytoczony wyżej fragment $₫ 28$. To w nim królewiecki filozof dzieli się opinią - powtórzmy - jakoby długotrwały pokój wiódł do upodlenia sie sposobu myślenia narodu. Nie ten fragment Krytyki wtadzy sądzenia wydaje się jednak reprezentatywny dla jego poglądów o wojnie. Zwróćmy choćby uwagę na zastrzeżenie zawarte w rozpoczynającym go zdaniu: Nawet wojna, jeśli prowadzona jest z zachowaniem porządku iposzanowaniem praw obywatelskich [...]. Jest to raczej wyraz myślenia życzeniowego aniżeli apoteoza wzniosłego charakteru wojen.

Jeszcze ważniejszy dla filozofii wojny Kanta wydaje się $\$ 83$ Krytyki wtadzy sądzenia. Wskazane jest przytoczenie jego dłuższego fragmentu: $W$ braku takiego systemu [kosmopolitycznej całości wszystkich państw - R.K.] i zpowodu przeszkód, jakie nawet możliwości takiego projektu stawiaja ambicja, żądza panowania oraz chciwość zwtaszcza tych, którzy maja wtadzę w rękach, rzeczq nieunikniona jest wojna [...]. Jako nie zamierzona przez ludzi [...], choć gtęboko ukryta, może zamierzona przez najwyższa mądrość próba, jeśli nie wprowadzenia, to jednak przygotowania stanu praworządności potaczonego z wolnościa państw, a dzięki temu też jedności ich moralnie ugruntowanego systemu, pomimo najstraszliwszych klęsk, jakie sprowadza ona na ród ludzki, i może jeszcze większych, jakimi uciska go state do niej pogotowie w czasie pokoju, stanowi ona (gdy nadzieja na spokojny stan szczęśliwości ludu coraz bardziej się oddala) jeden bodziec więcej do tego, by wszystkie talenty stużace kulturze doprowadzić do najwyższego rozwojü2. Nie znajdujemy tu gloryfikacji wojny. Perspektywa niezaangażowanego obserwatora pozwala natomiast dostrzec jej inną, mniej spektakularną, lecz lepszą stronę, mianowicie to, że wojna może przyczyniać się do aktywizacji twórczych sił ludzi. Służyć one mają osiągnięciu stanu, który autor Krytyk w swej filozofii prawa i polityki uznaje za ostateczny cel ludzkości w wymiarze społecznym, to znaczy civitas gentium obejmującą wszystkie ludy ziemi. Warunkiem jej utworzenia pozostaje dla Kanta w wymiarze politycznym ustanowienie związku pokojowego (foedus pacificum) urzeczywistniającego ideę wiecznego, czyli trwałego, pokoju ${ }^{23}$. Paradoksalnie wojny mogą przyczyniać się do jego powstania, ponieważ aktywizują wśród ludzi doświadczających ich skutków chęć zmiany tego, co złe, na lepsze. Wśród samych państw mogą one natomiast wpływać na kształtowanie się świadomości istnienia innych państw i narodów, które winny być traktowane nie tyle jako środek realizacji własnych interesów, ile jako samoistne podmioty, których prawa, przede wszystkim prawo do istnienia, muszą być przestrzegane. W ten oto sposób uzyskuje Kant argument na rzecz udzielenia twierdzącej odpowiedzi na pytanie postawione w tytule jednej ze swych rozpraw z filozofii historii: czy rodzaj ludzki zmierza ku temu, co lepsze ${ }^{24}$

22 I. Kant, Krytyka wtadzy..., 394, \$83, s. 426-427.

23 Tenże, Do wiecznego pokoju..., s. 63.

24 Zob. przyp. 12. 
Królewiecki filozof okazuje się więc orędownikiem wiary w postęp. Jest wręcz przekonany o stałym podążaniu przez gatunek ludzki po drodze postępu; drodze, którą znaczą również - czemu nie przeczy - wojny. Czy przekonanie to nie jest jednak sprzeczne z jego filozofią praktyczną, która w centrum stawia godność człowieka i jej ochronę? Rzeczywiście pojawiają się w tym zakresie wątpliwości. Hannah Arendt sarkastycznie określa Kanta mianem „osobliwego rodzaju pacyfisty”; osobliwego, nie pragnie on bowiem zniesienia wojen w celu wyeliminowania konfliktów czy nawet okrucieństwa, rozlewu krwi i potworności działań wojennych ${ }^{25}$. W konsekwencji sama idea postępu - twierdzi Arendt - o ile oznacza coś więcej niż zmianę okoliczności i ulepszania świata, stoi w sprzeczności z Kantowskim pojęciem godności cztowieka. Wiara w postęp jest sprzeczna z ludzka godnością ${ }^{26}$. Rozważmy ten zarzut.

Wehikułem postępu, jaki może nieść ze sobą wojna, jest - zdaniem Kanta - różnorodność narodów i dokonująca się poprzez wojenną konfrontację wymiana ich doświadczeń, wiedzy i oczekiwań. Wojna prowadzić więc może do pokoju na skutek chęci spożytkowania i wdrożenia w życie osiągnięć zaobserwowanych u innych nacji, czego nie da się dokonać w trakcie działań wojennych. Niezbędne są do tego stosunki pokojowe. Wymiana doświadczeń między ludźmi wywodzącymi się z różnych tradycji politycznych i kultur nie jest bynajmniej przeznaczeniem, lecz ukrytym przed ludźmi „fortelem przyrody” czy „fortelem historii”, jak to określa Kant. Człowiek w tym mechanizmie to wedle niego „końcowy cel przyrody”, w odniesieniu do którego wszystkie inne przedmioty przyrody stanowią system celów ${ }^{27}$. Przeznaczeniem człowieka w tej perspektywie okazuje się „państwo celów”, o czym niżej. Tymczasem zajmijmy się ukazaniem związków ludzi z ich naturalnym otoczeniem, czyli z przyrodą. Cel, jaki człowiek realizuje w świecie dzięki związkom z przyrodą, przedstawia się dwojako. Może nim być szczęśliwość bądź kultura ${ }^{28}$. Pojęcie szczęśliwości to dla Kanta idea pewnego stanu, który człowiek pragnie ustanowić w czysto empirycznych warunkach, co uważa on za niemożliwe. Bezrozumność przyrodzonych skłonności człowieka sprowadza nań niezamierzone przez niego utrapienia (np. tyrania władzy, barbarzyństwo wojen), które pełnić mają funkcję środków służących zapewnieniu wyimaginowanej i empirycznie ugruntowanej szczęśliwości. W rezultacie jednak środki te zagrażają całej ludzkości. Sama przyroda, jako coś przeciwnego wolności, nie może zapewnić ludzkości szczęścia, ponieważ natura ludzka nie jest na tę szczęśliwość podatna; nie zaspokaja ona oczekiwań człowieka jako racjonalnej i wolnej istoty. Człowiek dzięki intelektowi posiada jednak zdolność dowolnego wyznaczania sobie samemu celów, czyli również przekraczania naturalnych, empirycznych ograniczeń. $Z$ tego właśnie względu pozostaje końcowym celem przyrody ${ }^{29}$. Jest nim jednak tylko warunkowo, podkreśla królewiecki filozof. Jest nim mianowicie o tyle, o ile umie i chce nadać przyrodzie i sobie samemu takie celowe odniesienie, które

\footnotetext{
25 H. Arendt, Wyktady..., s. 135. Zob. też przyp. 7 i 8.

26 H. Arendt, Wyktady..., s. 140.

27 I. Kant, Krytyka wtadzy..., 388, $\$ 83$, s. 421.

28 Tamże, 388, s. 422.

29 Tamże, 390, s. 423.
} 
niezależnie od praw przyrody mogłoby być samowystarczalne, a zatem przedstawiałoby się jako cel ostateczny, którego nie należy szukać w samej przyrodzie ${ }^{30}$.

Używając terminologii z Kantowskiej metafizyki moralności, rzec można, że noumenalnej, wolnej natury człowieka nie należy sprowadzać do przyrody i wyjaśniać w ramach jej praw. Człowiek jako byt wolny, wręcz skazany na wolność, pozostaje zdolny do traktowania przyrody jako środka odpowiadającego jego wolnym celom. Te cele człowiek wyznacza i realizuje w kulturze za pośrednictwem przyrody. A więc tylko kultura - głosi Kant - może być końcowym celem, jaki mamy podstawe przypisywać przyrodzie wo odniesieniu do rodu ludzkiego (nie zaśjego wtasna szczesśliwość na ziemi albo nawet rola najważniejszego narzędzia stużącego do ustanawiania tadu $i$ harmonii w bezrozumnejprzyrodzie poza nim) ${ }^{31}$.

Kant nie ignoruje przy tym wynikających z zakorzenienia ludzi w przyrodzie i w tym znaczeniu - naturalnych warunków życia. Istoty rozumne mają je przekraczać, lecz nie mogą ich lekceważyć. Dlatego też przedstawienie Kantowskiego ideału w jego filozofii praktycznej - „państwa celów” - możliwe jest tylko przy użyciu analogii do „państwa przyrody”. To pierwsze, pamiętajmy, może być tworzone jedynie na podstawie maksym (nach Maximen), czyli autonomicznych, samemu sobie nakładanych prawideł postępowania, drugie zaś na mocy praw (nach Gesetzen), czyli przyczyn sprawczych narzucanych z zewnątrz ${ }^{32}$.

Nie każda kultura - zastrzega królewiecki filozof - pozwala na osiągnięcie tego końcowego celu przyrody, jaki w ostateczności wyznaczają ludzie wolni. Nad kulturą zręczności góruje tu kultura karności (dyscypliny). Ta druga bowiem polega na uwolnieniu woli od „despotyzmu żądz”, na skutek których ludzie stają się niezdolni do wolnego wyboru. To właśnie poprzez owe żądze - nieokiełznane ambicje, wolę sprawowania władzy, chciwość - wojny w panoramie ludzkich dziejów jawią się jako coś nieuniknionego. Nie są one jednak celem samym w sobie, czyli celem zamierzonym przez ludzi wolnych. Stanowią ,jedynie” środek realizacji nieokiełznanych namiętności. Ich okrucieństwo - i w tym przejawia się wspomniany „fortel przyrody” - stanowi bodziec służący doprowadzeniu do najwyższego rozwoju wszystkich talentów służących kulturze, czyli w rezultacie do położenia wojnom kresu.

Pozytywnym skutkiem wojen jest więc rozwój kultury karności, która służy krzewieniu wśród ludzi zdolności do wybicia się na wolność i utworzenia wspomnianego „państwa celów”. W nim - państwie celów jako królestwie istot wolnych - nie ma miejsca na wojny, ponieważ brak w nim warunków uzasadniających ich wszczynanie i prowadzenie. To w tym państwie prawo podstawowe głosi, że żadna istota rozumna nie powinna nigdy traktować sama siebie ani nikogo innego jako środek, lecz zawsze jako cel sam w sobie. Tylko w państwie celów może się urzeczywistnić prawdziwa umowa pierwotna, czyli umowa konstytuująca wspólnotę i oparta na imperatywie kategorycznym stanowiącym jądro metafizyki moralności.

\footnotetext{
30 Tamże, 391, s. 424.

31 Tamże, 391-392, s. 424.

32 Zob. I. Kant, Uzasadnienie metafizyki moralności, przeł. M. Wartenberg, Warszawa 1984, s. 76.
} 
W państwie celów całość wszystkich celów, to jest zarówno każdej istoty rozumnej jako celu samego w sobie, jak i ich własnych jednostkowych celów, da się pomyśleć w systematycznym związku. Bez wolności opartej na autonomii woli ukonstytuowanie się tak rozumianego państwa celów nie jest możliwe. Jego członkami mogą być tylko istoty rozumne, czyli postępujące według zasad wolności, tak jak gdyby były one prawami przyrody ${ }^{33}$. Toteż do czasu wybicia się ludzi na wolność, wojny, zdaje się głosić Kant, okazują się czymś nieuniknionym, zaś idea państwa celów to „jedynie” ideał służący do wzbudzenia wśród istot rozumnych żywego zainteresowania się prawem moralnym ${ }^{34}$. $\mathrm{Z}$ perspektywy jednostek uczestniczących w wojnach są one zawsze dramatem, ponieważ depczą godność człowieka bądź stanowią dla niej stałe zagrożenie. Jednak tak jak sceptycyzm zdolny wybudzić jest rozum teoretyczny z „metafizycznej drzemki”, tak skutki wojen władne są otrząsnąć ludzi z moralnego odrętwienia. To najważniejsza zaleta ich trwania i zarazem lekcja zadana ludzkości do odrobienia.

Pozycja filozofa-obserwatora beznamiętnie patrzącego na wojnę nie pozostaje w rezultacie w opozycji do podmiotu moralnego, kierującego się w swych ocenach rozumem praktycznym, który bezwarunkowo potępia wojnę. Filozof-obserwator bowiem dzięki poznaniu zdobywa wiedzę, która może znaleźć zastosowanie w praktyce. Wszak, jak głosił Kant, ostatecznie wszystko zmierza ku temu, co praktyczne: i na tym dązeniu wszystkiego, co teoretyczne, oraz wszelkiej spekulacji ze względu na ich użytek polega praktyczna wartość naszego poznania [...]. Jedynym bezwarunkowym i ostatnim celem (celem ostatecznym), do którego w końcu odnosić się musi wszelki praktyczny użytek naszego poznania, jest moralność, która z tego powodu nazywamy również tym, co catkowicie lub absolutnie praktyczne $e^{35}$. Wiedza o wojnach, ich przyczynach, a zwłaszcza skutkach służyć więc może moralnemu rozwojowi człowieka i przyczyniać się tym samym do ograniczania wojen. W tej perspektywie filozofia nie występuje w roli oderwanej od życia spekulacji. Przeciwnie, przeznaczeniem poznania, jakie daje filozofia, jest kształtowanie jednostkowego i społecznego życia i prowadzenie do wspomnianego państwa celów.

W państwie celów w najpełniejszy sposób urzeczywistnia się ideał państwa jako zjednoczenia wolnych istot rozumnych pod panowaniem wspólnych zasad prawnych ${ }^{36}$. W państwie celów wspólistnieje i da się uzgodnić całość najważniejszych celów wszystkich istot rozumnych dzięki podleganiu obowiązkowi nakazującemu traktowanie siebie samego i wszystkich innych jako celu samego w sobie. Przestrzeganie tego imperatywu daje rękojmię ustanowienia i związania wszystkich ludzi przez wspólne prawa. W konsekwencji podleganie imperatywowi kategorycznemu upodmiotawia członków państwa celów i przygotowuje do roli jego pełnoprawnych obywateli.

Ten Kantowski ideał, obok wydźwięku moralnego, ma również wyraźny wymiar polityczny ${ }^{37}$. Etyka i polityka pozostają w myśli Kanta współzależne. To etyka

33 Tamże, s. 68-69, 110.

34 Tamże, s. 110.

35 I. Kant, Logika. Podręcznik do wyktadów, przeł. A. Banaszkiewicz, Gdańsk 2005, s. 112.

36 Tenże, Uzasadnienie..., s. 68; tenże, Metafizyka..., 313, s. 154.

37 Por. E. Nowak-Juchacz, Autonomia..., s. 65. W każdym razie ideał ten ma w pełnym tego słowa znaczeniu wymiar praktyczny. 
i przestrzeganie w życiu jej zasad kształtuje jakość politycznej praktyki. Oznacza to niemożność ustanowienia państwa celów bez moralnej odnowy. Jeśli Kanta określić możemy mianem rewolucjonisty, to wzywa on „jedynie” do rewolucji rozumu, zarówno w jego wymiarze teoretycznym, jak i praktycznym, czyli rewolucji w poznaniu i rewolucji moralnej. Ta druga nie może się dokonać bez uznania przez każdego i w każdym z ludzi znaczenia wolności będącej ponadzmysłowym pierwiastkiem ich natury i warunkiem autonomicznych decyzji praktycznych. Tylko bowiem takie podmioty zdolne są do utworzenia państwa celów. Jednostki heteronomiczne, jako podmioty niezdolne do wolności bądź nieprzejawiające woli do wybicia się na wolność, zdane pozostają jedynie na podleganie prawom tworzonym przez innych. Nie mogą ich więc wiązać prawa wspólne w pełnym tego słowa znaczeniu, co prowadzi do niejako naturalnego podziału na rządzących i rządzonych. Tymczasem istota rozumna musi uważać się zawsze za prawodawcza w państwie celów możliwym dzięki wolności woli, bez względu na to, czy jest jego cztonkiem, czy zwierzchnikiem ${ }^{38}$. To dopiero w państwie celów dojść może do pełnego urzeczywistnienia samostanowienia ludzi poprzez wcielenie w życie maksymy: nic o nas bez nas.

W wymiarze ogólnoświatowym królewiecki filozof rozwija idę̨ państwa praworządnego tworzonego przez ludzi wolnych w ramach koncepcji civitas gentium obejmującej docelowo wszystkie narody i państwa ziemi. Jest to, dopowiedzmy, społeczność, w której urzeczywistniony został wieczny, czyli trwały, pokój, a więc perspektywa świata bez wojen. Jedynie ludzie wolni, powtórzmy raz jeszcze, zdolni są do utworzenia takiego świata. I nie chodzi tu o wolność polityczną, bo tę nominalnie mieć mogą również ludzie niechcący z niej korzystać, lecz o wolność egzystencjalną i moralną stanowiącą o podmiotowej autonomii człowieka. Ta druga warunkuje rzeczywistą wolność polityczną. W perspektywie filozofii Kanta jedynie ludzie wolni mogą ustanowić świat wolny od wojen, ponieważ etyka poprzedza i warunkuje politykę, zaś świadomość kształtuje byt społeczny.

Patrząc na liczne konflikty zbrojne we współczesnym świecie, konstatacja o braku w nim civitas gentium nie może budzić zdziwienia. Różnie, choć zazwyczaj standardowo, wręcz stereotypowo, tłumaczy się przyczyny wojen. Wskazuje się więc głównie na uwarunkowania polityczne, ekonomiczne, ideologiczne i religijne. Krocząc ścieżką rozumowania Kanta, można postawić jednak pytania bardziej zasadnicze, mianowicie: czy ustanowienie świata wolnego od wojen możliwe jest przez emanujące samozadowoleniem szerokie rzesze społeczne w zamożnych demokratycznych państwach?; rzesze stawiające znak równości między wolnością i samowolą?; rzesze przedkładające nad wolność „chleb i igrzyska”, z czym, co więcej, utożsamiana bywa przez nie życiowa „samorealizacja”?; rzesze uciekające od wolności i odpowiedzialności i dlatego bez większych oporów przekazujące innym podejmowanie w wymiarze politycznym decyzji kształtujących ich życie, pod warunkiem - naturalnie - nieobniżania przyznanego wcześniej socjalnego standardu „samorealizacji”?

Nie są to pytania ani łatwe, ani wygodne. Należy je jednak stawiać i szukać na nie odpowiedzi, ponieważ kryzys demokracji, o jakim możemy dziś mówić w wielu bogatych

38 I. Kant, Uzasadnienie..., s. 69. 
państwach świata, nie wynika z braku w nich instytucji i mechanizmów demokratycznych, lecz braku woli wspólnego podejmowania decyzji i brania za nie odpowiedzialności. Równolegle do procesu odsuwania odpowiedzialności i wolności obserwujemy narastającą obojętność wobec okrucieństwa wojen, zwłaszcza gdy dotyka ono członków obcych wspólnot. Wszak to „obcy giną”. To jednak autor tych słów - Josif Brodski - ma rację, pisząc w wierszu o dokonanym w byłej Jugosławii ludobójstwie na oczach świata, również tego tak zwanego cywilizowanego świata: W'ród wyznawców każdej wiary / sq mordercy i ofiary / twe milczenie wskaże teraz / kogo wspierasz ${ }^{39}$.

Ludzie wobec wojen, w których nie biorą bezpośredniego udziału, mogą zajmować dwojaką postawę: beznamiętnego obserwatora bądź kontestatora. Ten beznamiętny obserwator nie jest jednak Kantowskim obserwatorem, który chce zdobyć wiedzę w celu jej wykorzystania w praktyce. Jest raczej obojętnym podmiotem, który wiedzieć na dobrą sprawę nie chce, ponieważ nie chce też działać. Milczenie wobec zła wojen bądź protest wobec niego to test na moralną dojrzałość ludzi. Bez niej mniejsze lub większe wojny stanowić będą trwały element krajobrazu stosunków międzynarodowych i wewnątrzpaństwowych. Tę diagnozę wyprowadzić można z Kantowskiej filozofii politycznej.

Kant nie był pacyfistycznym utopistą. Co najwyżej, kierował się w odniesieniu do problemu wojen wiarą filozoficzną, to znaczy przekonaniem, że prawda o ludziach i świecie, jaką daje filozofia, może znaleźć urzeczywistnienie w praktyce, to znaczy prowadzić do stopniowego ograniczania i wreszcie eliminacji wojen. Może, lecz nie musi, i tego stanu rzeczy sam „fortel przyrody” nie zmieni. Jedynie ludzie i ich egzystencjalna dojrzałość wyrażająca się w czynach będących skutkiem ich wolnych decyzji mogą doprowadzić do takiej zmiany na lepsze i dostarczyć filozofom uzasadnienia twierdzącej odpowiedzi na pytanie, czy „rodzaj ludzki stale zmierza ku temu, co lepsze?”. Bez moralnej dojrzałości ludzkości zmiana taka - powtórzmy - się nie dokona.

Od śmierci Kanta upłynęło ponad 200 lat. W tym czasie doszło z jednej strony do znaczącej reglamentacji prawnej w zakresie używania siły zbrojnej, jednak z drugiej strony ludzkość zbyt rzadko dowodziła swej moralnej dojrzałości. Wciąż pozostaje raczej w tym względzie na etapie choroby wieku dziecięcego. Przejawy odnowy, jakie zazwyczaj można obserwować po zakończonych konfliktach zbrojnych, są krótkotrwałe i nie zapobiegają wybuchowi kolejnych konfliktów. W tym znaczeniu „wieczny pokój” to lekcja, której ludzkość jeszcze nie odrobiła. Również mechanizmy prawa międzynarodowego dotyczące zapobiegania konfliktom zbrojnym bądź pozwalające na szybkie kończenie toczących się wojen okazują się w praktyce niewystarczające. Nie dzieje się jednak tak dlatego, że ich materialna substancja nie jest zadowalająca. To wola ich wykorzystania przez podmioty upoważnione do tego przez reguły prawa pozostawia wiele do życzenia. Przede wszystkim chodzi o Radę Bezpieczeństwa ONZ i jej członków, których bezczynność w wielu sytuacjach prowadziła do braku reakcji na masowe naruszenia praw człowieka podlegających ochronie w międzynarodowym porządku prawnym. Konsekwencją tych zaniechań było nieraz jednostronne i prawnie kontrowersyjne

39 J. Brodski, Piosenka o Bośni, przeł. R. Kołakowski. 
użycie siły zbrojnej przez konkretne państwa poza systemem zbiorowego bezpieczeństwa. Rzadko takie doraźne uciekanie się do wojny prowadziło do stabilizacji sytuacji i wygaszania konfliktów. Najbardziej chyba dramatycznym i spektakularnym potwierdzeniem tej tezy pozostaje do dnia dzisiejszego sytuacja w Iraku, będąca skutkiem dokonanej tam bez autoryzacji ONZ interwencji zbrojnej w 2003 r.

Powyższe uwagi skłaniają do następującej konkluzji. Posiadana wiedza o człowieku i stosunkach międzyludzkich, jaką daje poznanie filozoficzne, oraz obowiązujące regulacje prawne same w sobie nie stanowią warunków wystarczających do pojawienia się pozytywnych zmian w świecie. Do tego, oprócz woli wiedzy i znajomości prawa, potrzebne są konkretne działania praktyczne wymagające zaangażowania. Sami obserwatorzy i wiedza, jaką mogą zaoferować, świata nie zmienią. Bez woli czynnego, praktycznego zaangażowania wdrożenie tej wiedzy w życie nie jest możliwe, tak więc uczestnicy muszą uzupełniać rolę odgrywaną przez obserwatorów. Niestety, jak pokazuje praktyka, uczestnicy konfliktów zbrojnych nie zawsze przejawiają wolę wykorzystania wiedzy, jaką o wojnach posiedli dzięki niezaangażowanym obserwatorom. Wola wykorzystania tej wiedzy w celu zapobiegania wojnom lub ograniczania ich skutków rodzi nierzadko dylematy dotyczące prewencyjnego bądź represyjnego użycia siły zbrojnej. Uprawnionym do działania w tym zakresie przypisać można nieraz grzech zaniechania. Jeden ze współczesnych komentatorów ocenia to następująco: Jeśli ONZ lub inna organizacja, a także państwa oferują rozwiązania dyplomatyczne, wiedząc z góry, że nie są sktonne (lub zdolne) posuną́ się w skrajnym przypadku do użycia sity, to ostabiaja swa pozycje, wzmacniają napastników i lekceważa ofiary. Okazuje się nazbyt często, że gotowych do umierania za Gdańsk, Sarajewo, Darfur... nie ma zbyt wielu, a niekiedy wręcz ich brakuje $e^{40}$. Nazbyt rzadko, niestety, uprawnieni i zobowiązani prawnie do działania kierują się w szczególności tym, co średniowieczna doktryna wojny sprawiedliwej określała jako „słuszną intencję” (recta intentio). To „słuszna intencja" pozwala w konkretnych sytuacjach na wyrwanie się z kokonu samozadowolenia i obojętności wobec toczących się „obok” wojen. Pozwala, innymi słowy, państwom i sprawującym w nich władzę na bycie rzeczywiście odpowiedzialnym za kształt relacji międzynarodowych. W tej mierze Immanuel Kant okazał się zbytnim optymistą. Parafrazując przywołane wyżej jego pytanie o wpływ wojen na bieg spraw w świecie, rzec można, że rodzaj ludzki zbyt wolno zmierza ku temu, co lepsze.

\section{BIBLIOGRAFIA}

Arendt H., What Is Freedom?, [w:] taż, Between Past and Future. Six Exercises in Political Thought, New York 1961.

Arendt H., Wyktady o filozofii politycznej Kanta, przeł. R. Kuczyński, M. Moskalewicz, Warszawa 2012.

40 J. Kranz, Wojna, pokój czy uspokajanie? Wspótczesne dylematy użycia sity zbrojnej, Warszawa 2006, s. 95. Por. też D. Fisher, Morality and War. Can War be Just in the Twenty-first Century?, Oxford 2011, s. 243-258; G.P. Fletcher, J.D. Ohlin, Defending Humanity. When Force Is Justified and Why?, Oxford 2008, s. $174-176$. 
Clausewitz C. von, O wojnie, przeł. A. Cichowicz, L. Koc, t. 1, Warszawa 1958.

Fisher D., Morality and War. Can War be Just in the Twenty-first Century?, Oxford 2011.

Fletcher G.P., Ohlin J.D., Defending Humanity. When Force Is Justified and Why?, Oxford 2008, Hegel G.W.F., Zasady filozofii prawa, przeł. A. Landman, Warszawa 1969.

Höffe O., Immanuel Kant, przeł. A. Kaniowski, wyd. 2 zm., Warszawa 2003.

Kant I., Do wiecznego pokoju. Projekt filozoficzny, [w:] tenże, O porzekadle: to może być stuszne $w$ teorii, ale nic nie jest warte $w$ praktyce. Do wiecznego pokoju. Projekt filozoficzny, przeł. M. Żelazny, Toruń 1995.

Kant I., Krytyka czystego rozumu, przeł. R. Ingarden, Kęty 2001.

Kant I., Krytyka wtadzy sadzenia, przeł. J. Gałecki, Warszawa 1986.

Kant I., Logika. Podręcznik do wyktadów, przeł. A. Banaszkiewicz, Gdańsk 2005.

Kant I., Metafizyka moralności, przeł. E. Nowak, Warszawa 2005.

Kant I., Odpowiedź na pytanie: czym jest Oświecenie?, przeł. M. Żelazny, [w:] tenże, Rozprawy z filozofii historii, przeł. T. Kupś i in., Kęty 2005.

Kant I., O porzekadle: to może być stuszne $w$ teorii, ale nic nie jest warte w praktyce, [w:] tenże, O porzekadle: to może być stuszne w teorii, ale nic nie jest warte w praktyce. Do wiecznego pokoju. Projekt filozoficzny, przeł. M. Żelazny, Toruń 1995.

Kant I., Uzasadnienie metafizyki moralności, przeł. M. Wartenberg, Warszawa 1984.

Kant I., Wznowione pytanie. Czy ludzki rodzaj stale zmierza ku temu co lepsze?, przeł. M. Żelazny, [w:] tenże, Rozprawy zfilozofii historii, przeł. T. Kupś i in., Kęty 2005.

Kranz J., Wojna, pokój czy uspokajanie? Wspótczesne dylematy użycia sity zbrojnej, Warszawa 2006.

Kwiecień R., Prawo w perspektywie filozofii Kanta, [w:] tenże, Między wartościa wspólnoty a wspólnota wartości. Studia i szkice z filozofii prawa idealizmu niemieckiego, Lublin 2007.

Nowak-Juchacz E., Autonomia jako zasada etyczności. Kant, Fichte, Hegel, Wrocław 2002.

Żelazny M., Idea wolności w filozofii Kanta, Toruń 1993.

Prof. dr hab. Roman KWIECIEŃ - absolwent prawa i filozofii, profesor nauk prawnych; członek Doradczego Komitetu Prawnego przy Ministrze Spraw Zagranicznych RP, Court of Conciliation and Arbitration within the Organization for Security and Co-operation in Europe (Genewa) oraz Permanent Court of Arbitration (Haga). 